\title{
APROXIMACIÓN A LA GEORREFERENCIACIÓN PARA LA INVESTIGACIÓN EMPRESARIAL
}

\section{APPROXIMATION TO GEORREFERENTIATION FOR BUSINESS RESEARCH}

\author{
Autor 1. Myriam Lucía Pineda González \\ Perfil e Institución: Docente Ocasional - Universidad Nacional Abierta y a \\ Distancia - UNAD
}

ORCID: https://orcid.org/0000-0002-0633-8040

Correo electrónico: myriam.pineda@unad.edu.co

\section{RESUMEN}

En el presente documento explora la definición y las potencialidades de la georreferenciación para la investigación en ciencias sociales, específicamente para al análisis del sistema empresarial.

Los instrumentos de información georreferenciados se usan en muchas áreas del conocimiento, para las ciencias empresariales y sociales, especialmente en un país tan diverso y con tantos asuntos por analizar territorialmente, resultan muy pertinentes y con mucho por explorar:

de acuerdo con (Pineda Gonzalez \& Matallana Kuan, 2017):

Más recientemente con el incremento de la cantidad información, se hace necesaria la organización y procesamiento de datos, desde distintas ramas de conocimiento se han fortalecido tendencias que lo permitan, es así como ahora se puede tener acceso a otras disciplinas académicas para mejorar el análisis complejo de la realidad, tal es el caso de la Neogeografía, la cual está entrando a ser corrientemente utilizada como herramienta para construir criterios guía para la toma de decisiones del estado, de las empresas y agentes económicos.

Palabras clave: Neogeografía; Información georreferenciada; Investigación empresarial; Encuestas georreferenciadas.

\section{ABSTRACT}

This document summarizes and exemplifies the potential of the use of georeferencing tools for social science research, specifically for the analysis of the business system.

Georeferenced information tools are used in many areas of knowledge, for business and social sciences, especially in such a diverse country and with so many issues to analyze territorially, they are very pertinent and with much to explore, according to (Pineda Gonzalez y Matallana Kuan, 2017, p. 3):

More recently with the increase in the amount of information, it is necessary to organize and process data, from different branches of knowledge have strengthened trends that allow it, this is how you can now have access to other academic disciplines to improve the complex analysis of reality, such is the case of Neogeography, which is currently being used as a tool to build guiding criteria for decision making by the state, companies and economic agents. 


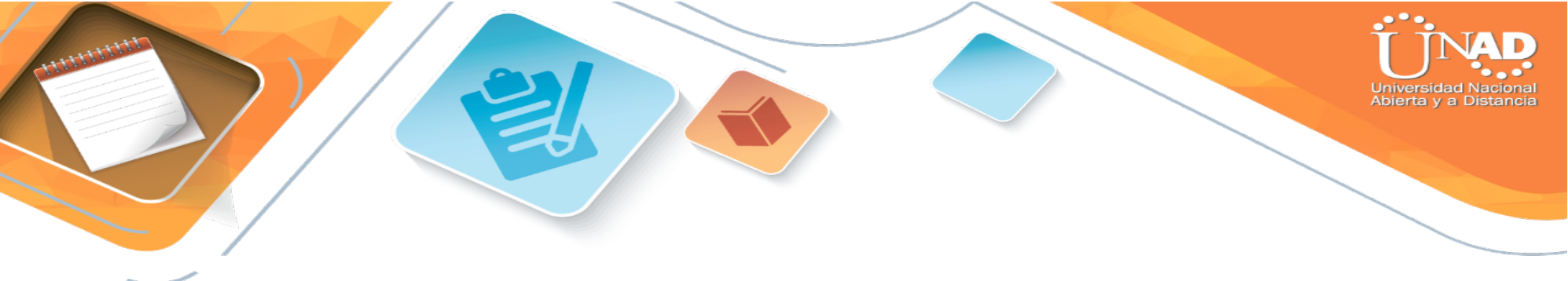

Es de hecho ya muy frecuente la institucionalización de iniciativas de ciencia participativa, de acuerdo con (Bosque Sendra, 2015): "una iniciativa territorial muy importante en este sentido es Open Street Map (www.openstreetmap.es) que está elaborando un amplio mapa callejero de todas, o de muchas ciudades del mundo".

Aunque es verdad que gran parte de la información social puede ser representada geográficamente, lo realmente trascendente es saber cuál es la mejor manera de hacerlo, por ello el proceso de diseño es muy importante y debe considerar unas premisas ideales, según (Pueyo-Campos et al., 2016, p. 7) serían:

Los objetivos. Hay que coordinar las aspiraciones lógicas de los individuos que viven y sufren ese espacio, y los deseos y planteamientos de los gestores políticos.

La definición de las variables, que pueden tener presentaciones no mensurables y, sin embargo, de ellas puede depender el éxito o fracaso del análisis.

La escala de presentación del problema. A diferente escala o ámbito de referencia, diferente grado de información y tratamiento de la misma. Esto es de vital interés si lo que se busca es la operatividad de los resultados, y la inteligibilidad de la cartografía resultante de los mismos.

El carácter diagonal de los estudios urbanos. Es necesario sopesar todos los valores dentro de un conjunto más amplio para que adquieran su auténtica dimensión $y$ eficacia.

\section{CONCLUSIONES}

Las innovaciones tecnológicas han tornado más amigable, barato y fácil el acceso a instrumentos que permiten georreferenciar información, lo cual ha redundado en el interés de ciudadanos comunes y de investigadores en generar sus propios datos geográficos.

De acuerdo con (Bosque Sendra, 2015): "la participación masiva de personas voluntarias en la realización de muchas y variadas tareas relacionadas con el territorio y la Geografía, está cambiando de manera sustancial la investigación geográfica".

La posibilidad de georreferenciar todo tipo de información puede facilitar el conocimiento de los territorios, las sociedades, la economía y su respectiva dinámica.

\section{REFERENCIAS}

Bauch, N. (2017). Digital Geohumanities: Visualizing Geographic Thought. International Journal of Humanities and Arts Computing, 11, 1-15. DOI:

https://doi.org/10.3366/ijhac.2017.0174

Bosque Sendra, J. (2015). Neogeografía, Big Data y TIG: problemas y nuevas posibilidades. Polígonos. Revista de Geografía, 0(27), 165. DOI:

https://doi.org/10.18002/pol.v0i27.3277

Oppenheimer, A. (2011). iBasta de historias! : La obsesión latinoamerican con el pasado y 



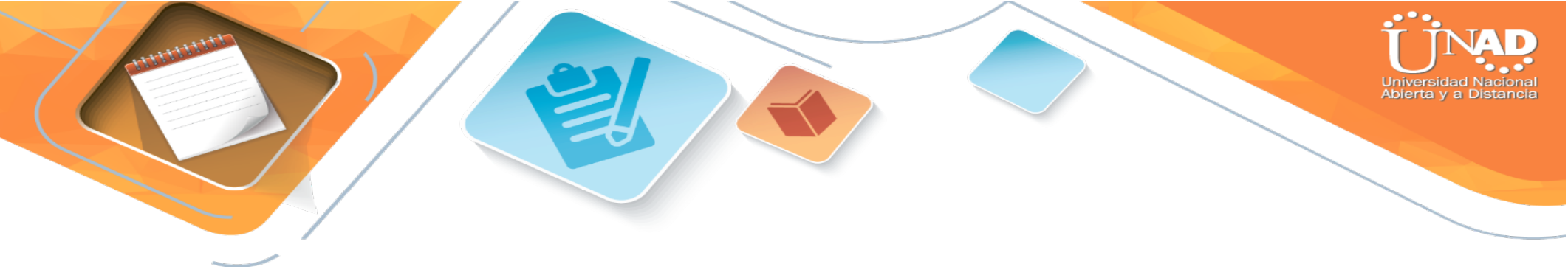

